Wojciech Kocot $^{1}$

ORCID: 0000-0002-9408-1985

Aleksander Wodyński ${ }^{2}$

ORCID: 0000-0001-6965-9848

\title{
CASE STUDY OF INSUFFICIENT RESISTANCE TO MINING IMPACTS OF THE INDUSTRIAL TRANSPORT GALLERY
}

\author{
${ }^{1}$ AGH University of Science and Technology, Kraków, Poland \\ wokocot@agh.edu.pl \\ ${ }^{2}$ AGH University of Science and Technology, Kraków, Poland \\ awodyn@agh.edu.pl
}

Keywords: conveyor galleries, mining impacts

\begin{abstract}
The article presents an example of a transport gallery, which resistance to mining impacts proved to be not enough. In the first part of the article, there are given the principles which should be followed by this type of structures. The second part presents a description of the gallery's structure and also the analysis of the reasons for too low resistance of the object to mining influences. It has been shown that these reasons are design, execution and exploitation errors. In turn, there are presented procedures which are leading to the assurance of the resistance of the transport gallery in accordance with design assumptions. In summary, conclusions and recommendations which are formulated should be taken into account at the stage of design, erection and during exploitation of transport galleries in the industrial plants localized in mining areas.
\end{abstract}

\section{ANALIZA PRZYPADKU NIEWYSTARCZAJĄCEJ ODPORNOŚCI NA WPLYWY GÓRNICZE PRZEMYSLOWEJ GALERII TRANSPORTOWEJ}

Słowa kluczowe: galerie transportowe, wpływy górnicze

\begin{abstract}
Abstrakt
W artykule przedstawiono przykład galerii transportowej, której odporność na wpływy górnicze okazała się niewystarczająca. W pierwszej części artykułu podano zasady, jakim powinny odpowiadać tego typu obiekty budowlane. W części drugiej przedstawiono opis konstrukcji przedmiotowej galerii oraz przeanalizowano przyczyny zbyt niskiej odporności obiektu na wpływy górnicze. Wykazano, że są to zarówno błędy projektowe, jak i wykonawcze oraz eksploatacyjne. Z kolei przedstawiono zabiegi zmierzające do zapewnienia galerii transportowej odporności zgodnej z założeniami projektowymi. W podsumowaniu sformułowano wnioski i zalecenia, które powinny być uwzględniane na etapie projektowania i budowy oraz podczas eksploatacji galerii transportowych w zakładach przemysłowych usytuowanych na terenach górniczych.
\end{abstract}

\section{INTRODUCTION}

In every industrial company there are building structures, the proper functioning of which is of crucial importance for the functioning of the entire enterprise.
These include transport galleries, especially when they are the only means of internal transport of key materials. These objects should be subject of special care in terms of inspections and maintenance procedures. In the case of location of the plant in the mining areas, they must 
also have appropriate preventive structural protection against mining impacts.

The article presents an example of a gallery whose resistance to mining influence due to committed design, execution and exploitation errors turned out to be insufficient.

\section{DESIGN PRINCIPLES OF TRANSPORT GALLERY STRUCTURES}

Transport of loose materials inside industrial plants is often carried out with the help of belt conveyors running inside conveyor bridges, which function as a load-bearing structure and conveyor housing at the same time. Similarly to the other bridge structures, transport galleries consist of free-supported spans, the number of which is usually from one to several, although in some cases it can be much higher quantity.

In practice, steel conveyor galleries are the most common. The dominant spans are of spatial truss structure, where the load-bearing system is composed of the two parallel flat trusses connected at the top and bottom by "X - type" braces and wind system bracing. Less frequently, there are so-called shell galleries, based on the construction of airplane fuselages. Their sheathing consists of metal plate, which thickness is form 3 to $5 \mathrm{~mm}$, reinforced with transverse frames and longitudinal ribs (Szulc 1960).

Single-span galleries usually realize the static scheme of the free-supported beam, supported on the one side on "fixed" bearings (non-sliding spherical plain bearings) and on the other side there are "movable" bearings (non-sliding spherical plain bearings). In the first case these are usually two stabilized tangential bearings and in the second case there are roller bearings (Szelągowski 1966, Rozporządzenie 2000, Kocot 2020). The possibilities of horizontal displacement on movable bearings which are resulting from thermal deformations of the span $s_{t}$ are calculated from the formula (Szelągowski 1966):

$$
s_{t}=l \cdot \Delta t \cdot \alpha
$$

where:

$l$ - theoretical range of a span (for diagonal galleries in plan) $[\mathrm{m}]$,

$\Delta t$ - temperature difference [degree Celsius],

$\alpha-$ thermal expansion coefficient [degree Celsius ${ }^{-1}$ ].
In the case of location of the gallery in mining areas, the needed possibilities of movement (so-called kinematic possibilities) should be increased by the values resulting from the de-formation of the ground (Rosikon 1978, Wytyczne 1977). If the course of the mining exploitation front is approximately parallel to the longitudinal axis of the gallery, the needed possibilities of sliding are $s_{l}$ (Wytyczne 1977):

$$
s_{l}=L\left(\varepsilon+\frac{h}{R}\right)
$$

where:

$L$ - the distance between the centers of gravity of the supports [m],

$\varepsilon-$ horizontal deformation inherent in the mining area $[\mathrm{mm} / \mathrm{m}]$,

$h$ - height from the foundation level of the building supporting to the bearing axis [m]

$R$ - the radius of curvature of the mining area [km].

In the case of an oblique course of the exploitation front in relation to the gallery axis, an additional component resulting from the rotation of supports in relation to their vertical axis $s_{b}$ should be added (Wytyczne 1977):

$$
s_{b}=0,6 \cdot \varepsilon \cdot b
$$

where:

$b$ - distance between bearings of the same support [m].

Multi-span galleries are generally composed of simply supported beam girders. There are also two or more-span galleries with a continuous beam scheme. This static scheme is often used for sheathed galleries. Because of the possibility of curvature of the terrain it is not recommended to use it in case of location of galleries in mining areas.

Among the transport galleries diagonal galleries (so called slanting bridges) take a special place. They are used when the loading place and destination place are on different levels. The gallery being the subject of this article is one of them.

\section{GALLERY CONSTRUCTION DESCRIPTION}

The gallery which is the subject of the article (Figs. 1,2 ) is a load-bearing structure and housing for two belt conveyors transporting the ore from the shaft building to the ore haulage building situated above the rail- 


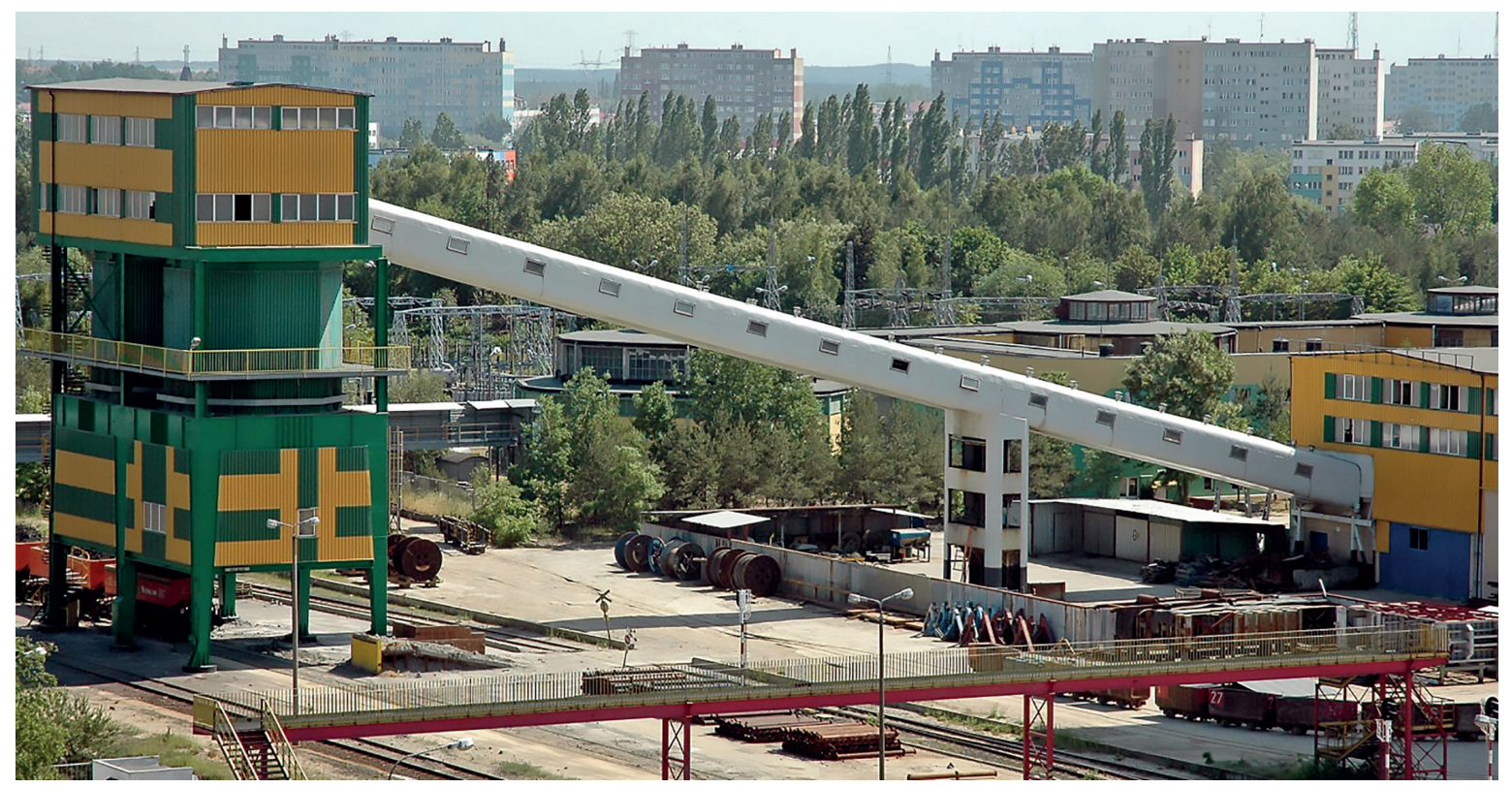

Fig. 1. The conveyor gallery - view from the north. On the left: the ore haulage building, on the right: a fragment of the shaft building Rys. 1. Galeria transportowa - widok od strony północnej. Po lewej budynek odstawy rudy, po prawej fragment budynku nadszybia

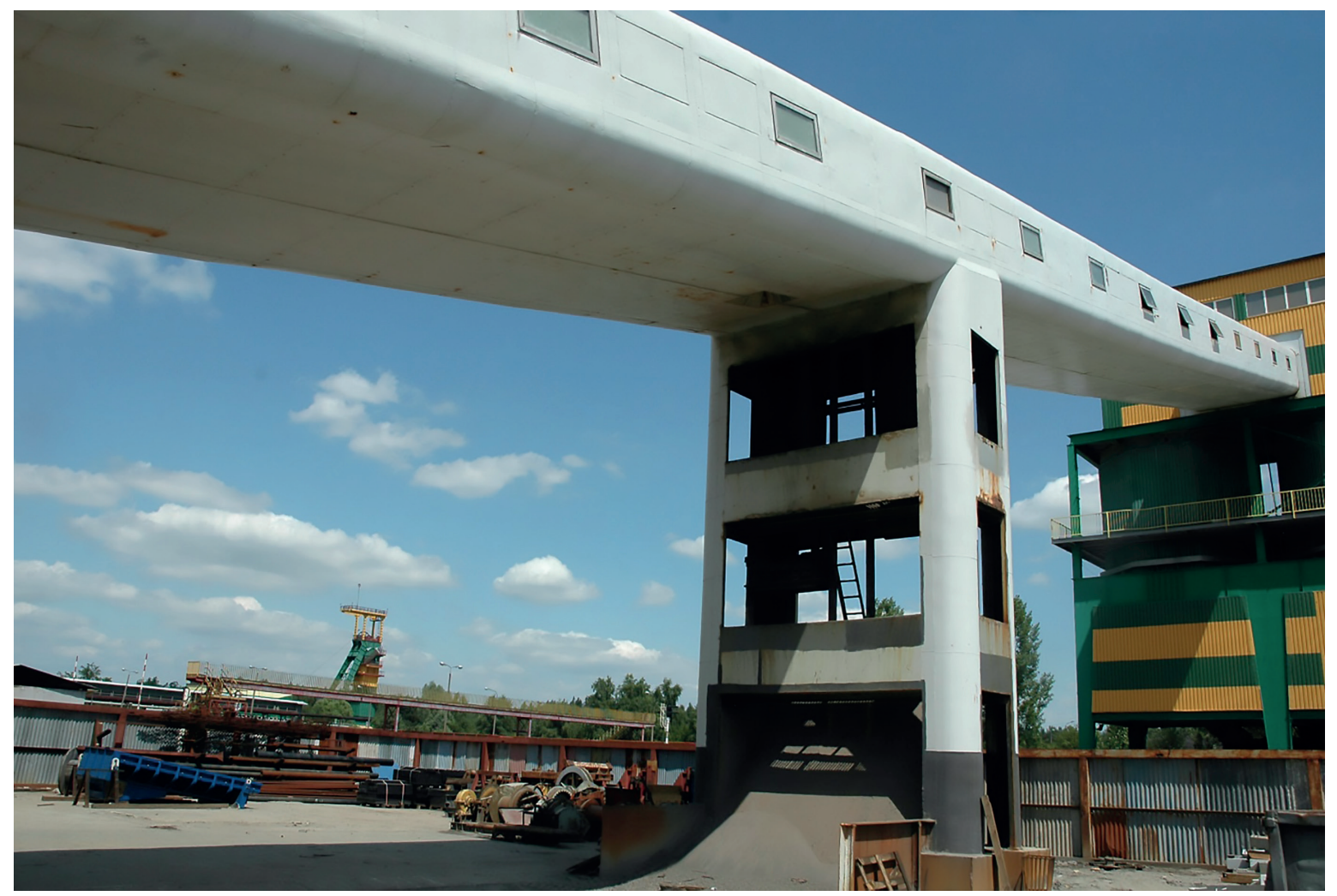

Fig. 2. The conveyor gallery - view from the south. On the right the ore haulage building, in the center the intermediate support Rys. 2. Galeria transportowa - widok od strony południowej. Po prawej budynek odstawy rudy, w środku podpora pośrednia 
road tracks. It is a two-span shell gallery. In the static scheme, it is a continuous beam with the spans in plan $23.3 \mathrm{~m}+41.7 \mathrm{~m}=65 \mathrm{~m}$ (Fig. 3). Due to the height difference between the loading point and the destination point, the gallery is inclined at an angle of $13 \mathrm{deg}$ to the horizontal. The lower end is supported on the shaft transfer station building and the upper end rest on the last ceiling of the ore haulage building. In both cases it is an articulated-sliding support realized with steel roller bearings. The intermediate support was constructed as a steel openwork shell (see Fig. 2). It is restrained in the reinforced concrete foundation footing and its connection with the gallery shell should be treated as stiff.

The load-bearing structure of the $5.4 \mathrm{~m}$ wide gallery is made of $4 \mathrm{~mm}$ thick steel sheet and stiffened by $1.5 \mathrm{~m}$ spaced transverse frames. The frames are made of two $50 \times 6 \mathrm{~mm}$ T-sections, which diverge at the bottom and roof parts, and cross-braces are welded between them form a truss (Fig. 4). The middle part of each frame is strengthened by two posts of $76 \mathrm{~mm}$ tube at $90 \mathrm{~cm}$ intervals. The longitudinal reinforcement is provided by ribs made of $80 \mathrm{~mm}$ I-beams and channels and $50 \times$ $6 \mathrm{~mm}$ T-bars.

Four steel single-shaft bearings were used to lean the gallery on. For the lower bearings, shafts with a diameter of $150 \mathrm{~mm}$ were used with bearing plate lengths of $300 \mathrm{~mm}$ (e.g. Figure 5). Two guides were welded to the upper and lower bearing plates, each hits the annular grooves of the rollers, so that lateral displacement has been prevented. Displacement limiters in the longitudinal direction were fitted at both ends of the guideways.
Shafts with a diameter of $220 \mathrm{~mm}$ were used for the upper bearings. The displacement limiters in longitudinal direction are steel transverse strips $25 \times 25 \mathrm{~mm}$ in diameter welded to the bearing plates and spaced 400 $\mathrm{mm}$ apart (e.g. fig. 6). No blocking of displacement in lateral direction is used.

\section{RESISTANCE TO MINING IMPACTS}

The present investigation only analyzed the issue of static resistance to mining impacts. The dynamic resistance assessment, which requires a different evaluation methodology, was not undertaken (Rusek etc. 2020).

The technical design provided for protection of the gallery against mining influences is corresponding to the II category of threat, i.e. $\varepsilon= \pm 3 \mathrm{~mm} / \mathrm{m}$ and $R=12 \mathrm{~km}$ (Wytyczne 1977). Due to the unfavorable static scheme (continuous beam), the static-strength calculations took into account the increase in stresses in the shell structure caused by the impact of uneven settlement of supports related to the curvature of the terrain. When there are designing sliding bearings, the influence of curvature and horizontal deformation of the terrain (equations 2 and 3) were taken into account in addition to thermal deformations (calculated according to formula 1). As a result, the gallery was equipped with bearings with the following kinematic capabilities:

$$
\begin{array}{ll}
\text { - bottom bearings: } & \pm 10 \mathrm{~cm}, \\
\text { - top bearings: } & \pm 20 \mathrm{~cm} .
\end{array}
$$

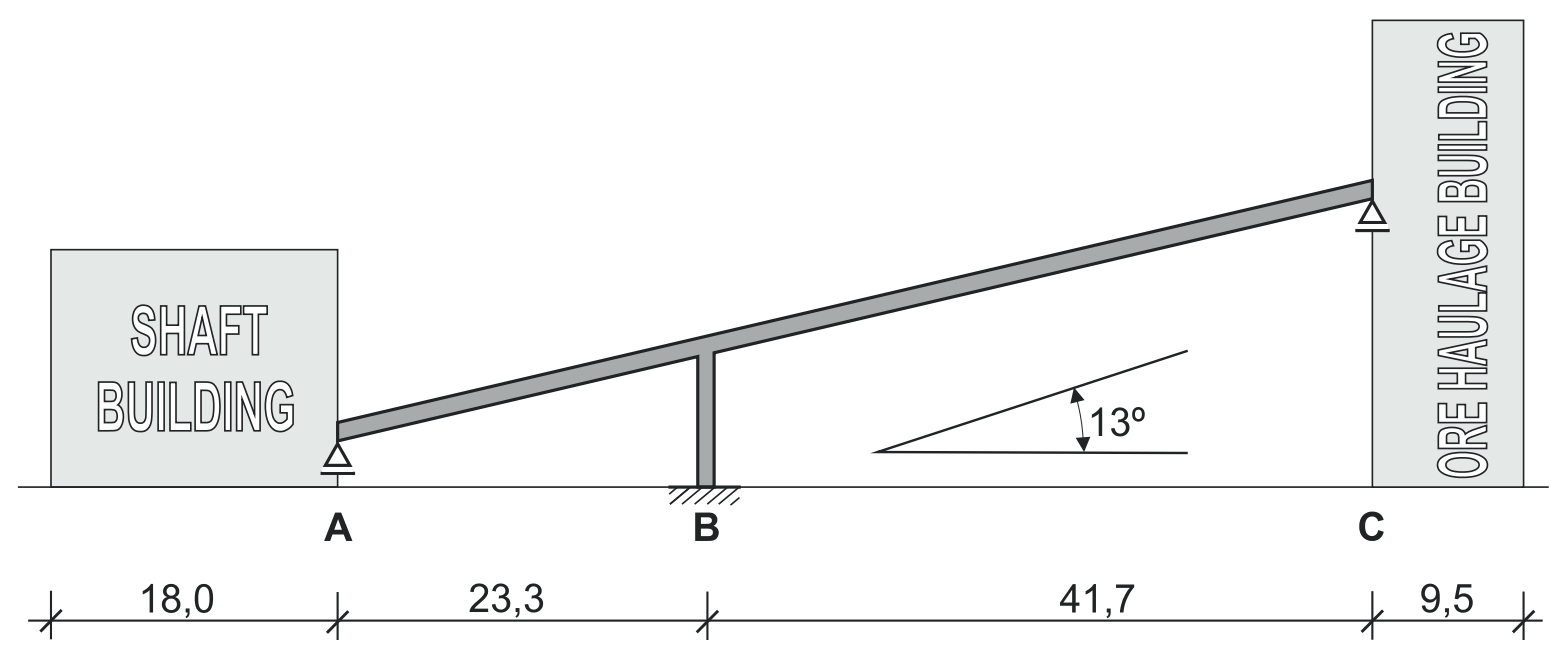

Fig. 3. Static diagram and basic dimensions of the gallery Rys. 3. Schemat statyczny oraz podstawowe wymiary galerii 


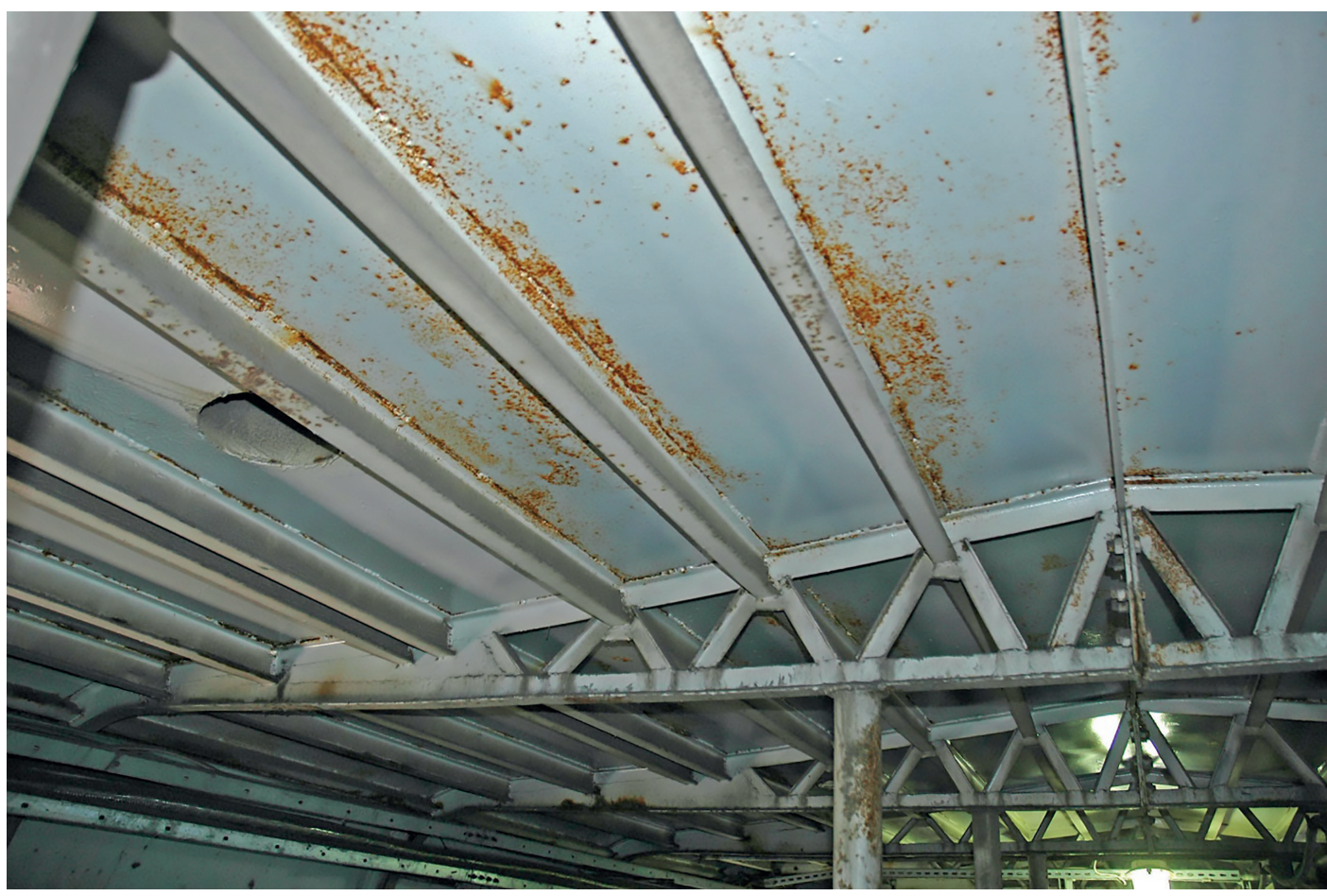

Fig. 4. Interior of the gallery - visible fragment of the roof section - steel structural elements and sheet metal Rys. 4. Wnętrze galerii - widoczny fragment części dachowej - stalowe elementy konstrukcyjne i blacha poszycia

However, in the most important part of calculations, i.e. formula (2), incorrect value of distance between centers of gravity of supports (variable $L$ ) was assumed. The lower support is in fact the shaft top building and not the associated point A (see Figure 3). Therefore the correct value of $L$ for the calculation of the kinematic capacity of the lower bearing is not $23.3 \mathrm{~m}$ but $23.3+0.5 \times 18=32.3 \mathrm{~m}$. The similarly calculated correct value of $L$ for the upper bearing is $46.5 \mathrm{~m}$. After correcting the calculations, the required displacement values were respectively:

- for bottom bearings: $\pm 13,5 \mathrm{~cm}$,

- for top bearings: $\quad \pm 25,5 \mathrm{~cm}$.

However, this turned out not to be the biggest problem. During the inventory, it was found that the lower bearings were heavily corroded and contaminated, which blocked the ability of the shaft to roll on the lower plate. This was indicated by the far-from-central position of the shaft in relation to the bearing plates (e.g. fig. 5).

The plate-covered upper bearing proved to be even more effectively blocked (e.g. fig. 6). The intention of the designer was to protect bearings against contaminants, but he did not consider that it would block the operation of bearings much more effectively than the contaminants themselves.

Locking the shaft in a roller bearing does not completely block the gallery end overshoots relative to the support, but it does reduce these possibilities by half. As a result, the kinematic possibilities of the bearings became as follows:

- on bottom bearing: $\pm 5 \mathrm{~cm}$,

- on top bearing: $\quad \pm 10 \mathrm{~cm}$.

This was sufficient to achieve incomplete resistance to mining terrain category $\mathrm{I}$, with an approximate $\varepsilon=$ $\pm 1.0 \mathrm{~mm} / \mathrm{m}$ and $R=27 \mathrm{~km}$ (Wytyczne 1977). Due to the locking of the shafts in positions deviating from neutral, the actual kinematic possibilities were even smaller.

$$
\text { * * * }
$$

After reporting these observations to the Facility Manager, the bearings were cleaned, preserved and rectified. Additionally, plates blocking displacement of upper bearings were cut to appropriate length and the bearings themselves were otherwise protected against ore contamination. As a result of the above actions, the 


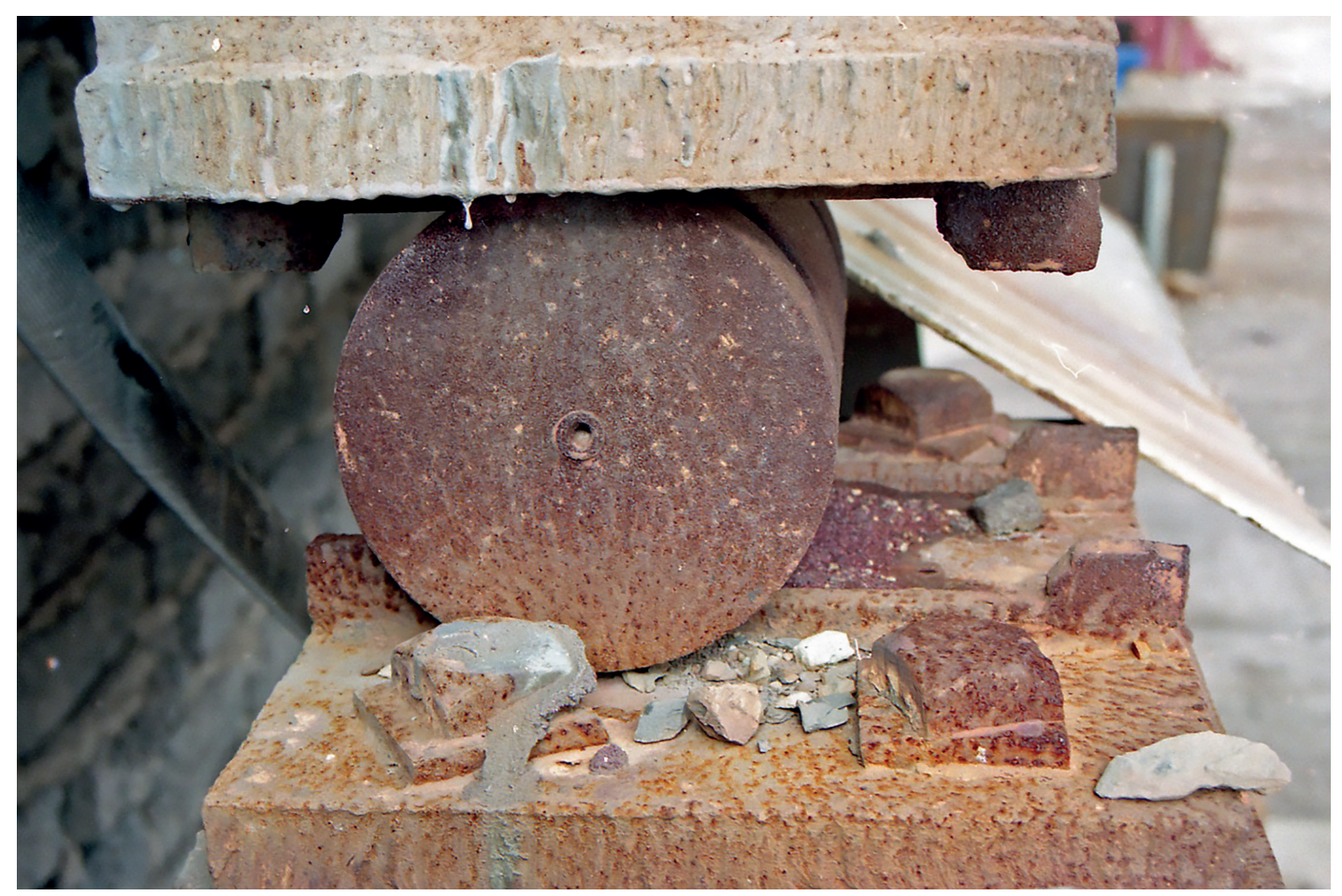

Fig. 5. Eastern lower bearing

Rys. 5. Łożysko dolne wschodnie

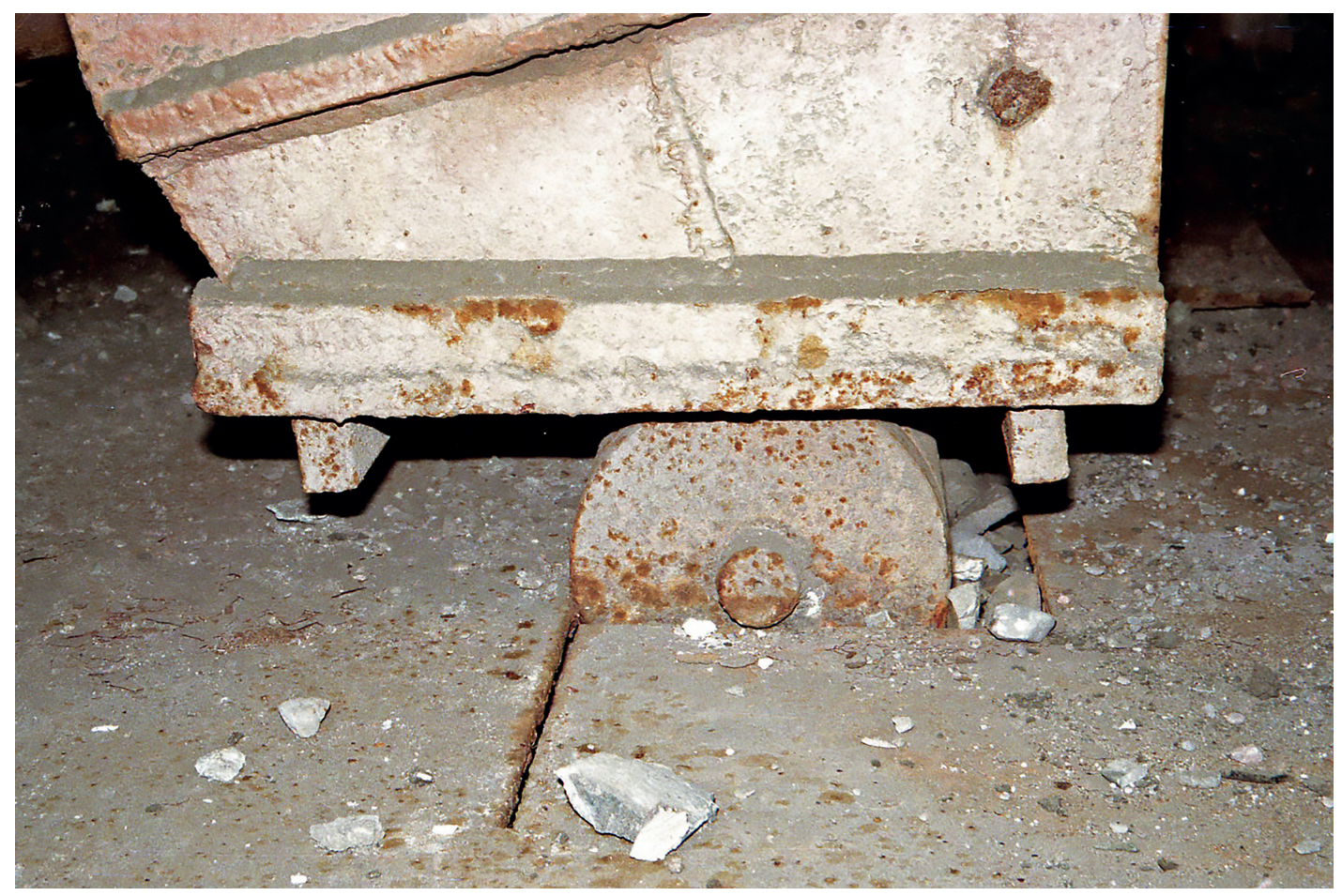

Fig. 6. Eastern upper bearing

Rys. 6. Łożysko górne wschodnie 
kinematic possibilities of the bearings assumed by the designer were achieved, i.e:

- on bottom bearing: $\pm 10 \mathrm{~cm}$,

- on top bearing: $\quad \pm 20 \mathrm{~cm}$,

which is sufficient to achieve incomplete resistance to mining site category II, namely $\varepsilon= \pm 2.5 \mathrm{~mm} / \mathrm{m}$ and $R=15 \mathrm{~km}$. To achieve the resistance envisaged in the design, i.e. to the full mining area category II, a minor modification of all four bearings would be required. In the case of the upper bearings, it would suffice to move the limiting strips. In the case of the lower bearings, the simplest option would be to remove the stops on the pro-rods and weld lateral stop strips further down to the ends of the bearing plates. However, this procedure, although technically relatively simple and inexpensive, was not implemented.

A separate problem is the applied static scheme. For bridges (such as transport galleries) erected in mining areas it is recommended to use statically determinate schemes (Wytyczne 1977, Rosikoń 1978). However, for the analyzed gallery the statically indeterminate continuous beam scheme was used. Additionally, after taking into account a rigid connection with an intermediate support fixed in the foundation, the static scheme may be regarded as framework. In combination with significant spans, the adopted solution should be considered very unfavorable.

This problem becomes particularly important when it is necessary to increase the resistance of the structure to mining impacts. While the increase of kinematic possibilities of the gallery bearings is technically not very complicated and it is possible to carry out with relatively small resources, the change of static system is completely impossible. When we are designing buildings in mining areas it should always be taken into account that the mining forecasts on which we base our designs are made for a time horizon of several years, while the assumed lifetime of such building structures is often even ten times longer.

\section{SUMMARY}

The article presents an example of a transport gallery, which resistance to mining impacts proved to be insufficient. This occurred as a result of errors in design, execution and exploitation. Relatively difficult to catch design error turned out to be insignificant - it caused only a small decrease of the object resistance. The most significant mistake, which consisted in blocking the displacements on the upper bearings with the casing sheet, was probably made on the contractor's initiative. At this point it is worth emphasizing the role of proper investor supervision, which should catch similar irregularities. If the supervisor does not react, these irregularities should be noticed during the technical acceptance of the investment.

As far as the static scheme is concerned, it is worth to base on recommended and tested solutions. This allows to avoid problems in case of necessity to increase the resistance of the structure, for example as a result of mining exploitation of successive seams.

\section{ACKNOWLEDGMENTS}

This research was funded by the AGH University of Science and Technology statutory fund 16.16.150.545 in 2021.

\section{REFERENCES}

Szulc Józef. 1960. „Stalowe galerie transportowe o konstrukcji powłokowej". Konstrukcje stalowe w budownictwie i mostownictwie. Pierwsza Konferencja Naukowo-Techniczna, Warszawa 6-9 lutego 1958 r. Wydawnictwo Arkady. Warszawa.

Szelągowski Franciszek. 1966. Mosty metalowe. Wydawnictwa Komunikacji i Łączności. Warszawa.

Rozporządzenie. 2000. Rozporządzenie Ministra Transportu i Gospodarki Morskiej z dnia 30 maja 2000 r. w sprawie warunków technicznych, jakim powinny odpowiadać drogowe obiekty inżynierskie i ich usytuowanie.

Rosikoń Antoni. 1978. Ułożyskowanie mostów na terenach eksploatacji górniczej. Ochrona Terenów Górniczych, no. 47, Katowice.

Wytyczne. 1977. "Wytyczne techniczno-budowlane projektowania i wykonywania obiektów mostowych na terenach eksploatacji górniczej” Załącznik do zarządzenia Ministra Komunikacji oraz Ministra Administracji, Gospodarki Terenowej i Ochrony Środowiska z dnia 23 września 1976 r. (Dziennik Urzędowy M.K. nr 31 poz 290 oraz Dziennik Urzędowy nr 5 poz. 13), Wydawnictwo Katalogów i Cenników, Warszawa.

Kocot Wojciech. 2020. Przedawaryjny stan galerii transportowej. Builder (Warszawa); no. 4, p. 68-71. https://builderscience.pl/resources $/ \mathrm{html} /$ article/details?id=199538

Rusek Janusz, Słowik Leszek, Firek Karol, Pitas Michał. 2020. Determining the dynamic resistance of existing steel industrial hall structures for areas with different seismic activity (Wyznaczanie odporności dynamicznej istniejacych hal przemysłowych o konstrukcji stalowej dla obszarów o różnej aktywności sejsmicznej). Archives of Civil Engineering. Polish Academy of Sciences. Institute of Fundamental Technological Research. Committee for Civil Engineeringvol. 66 no. 4, p. 525-542. DOI: 10.24425/ace.2020.135235. 